Гордана Штасни

Универзитет у Новом Саду

Филозофски факултет

Одсек за српски језик и лингвистику

gordanastasni@ff.uns.ac.rs

Гордана Штрбац

Универзитет у Новом Саду

Филозофски факултет

Одсек за српски језик и лингвистику

gordana.strbac@ff.uns.ac.rs

\section{Милан Ајџановић}

Универзитет у Новом Саду

Филозофски факултет

Одсек за српски језик и лингвистику

ajdzanovic@ff.uns.ac.rs
УДК 811.163.41'366'374

https://doi.org/10.18485/slavistika.2021.25.2.4

Стручни рад

примљено 4.7.2021.

прихваћено за штампу 6.10.2021.

\title{
ИНОВИРАНА КОНЦЕПЦИЈА СЕМАНТИЧКО-ДЕРИВАЦИОНОГ РЕЧНИКА СРПСКОГ ЈЕЗИКА НА ПРИМЕРУ ГНЕЗДА ЛЕКСЕМЕ РУНО*
}

Значајан допринос дериватологији и србистици уопште представљају Семантичкодеривациони речник. Свеска 1: Човек - делови тела (2003) и Семантичко-деривациони речник. Свеска 2: Човек - унутрашњи органи и ткива, психофизиолошка стања и радње, психофизичке особине, сродство (2006), у којима су у функцији мотиватора дати соматизми, називи унутрашњих органа и ткива, називи физиолошких стања и процеса. С намером да се настави истраживачки рад и испита семантичко-деривациони потенцијал тематски сродне и такође фундаменталне лексике у српском језику, какви су свакако називи делова тела и унутрашњих органа животиња, осмишљен је донекле иновирани концепт оваквог типа речника. У раду је предложена структура гнезда илустрована дериватима с мотивном речју руно.

Кључне речи: српски језик, семантичко-деривациони речник, деривационо гнездо, лексема руно.

A two-volume Semantic-Derivational Dictionary (Volume 1: Man - Body Parts (2003) and Volume 2: Man - Internal Organs and Tissues, Psychophysiological States and Actions, Psychophysical Characteristics, Kinship (2006)), in which names of the body parts, internal organs and tissues, etc. are given as motivating words of derivational nests, was greeted as a significant contribution to Serbian word formation. In order to continue the research work and examine the semantic-derivational potential of thematically related words, such as the names of the body parts and internal organs of animals, a somewhat innovative concept of this type of dictionary was devised. Thus this paper proposes a nest structure illustrated with derivatives from the motivating word runo (fleece).

Keywords: Serbian language, semantic-derivational dictionary, derivational nest, lexeme fleece.

* Овај рад представља део истраживања у оквиру пројекта Стандардни српски језик: синтаксичка, семантичка и прагматичка истраживаға (бр. 178004), који финансира Министарство просвете, науке и технолошког развоја Републике Србије. 
1. Уводне напомене

1.1. Напредак у развитку дериватологије српског језика и примена дотадашњих теоријских сазнања о творби речи, што је и својеврсни пресек стања у овој дисциплини у србистици, представљају Семантичко-деривациони речник. Свеска 1: Човек - делови тела (2003) и Семантичко-деривациони речник. Свеска 2: Човек-унутрашњи органи и ткива, психофизиолошка стања и радюе, психофизичке особине, сродство (2006). ${ }^{1}$ Д. Гортан Премк још 2000. године најавила је потребу за израдом лингвистичког речника овога типа и разрадила његову теоријску поставку и концепцију која се заснива на критеријуму тематске повезаности (што је видљиво у избору мотивних речи), уз придруживање семантичког и деривационог критеријума. „Деривациони критериј потврдио је претпоставку о зависности између броја и типа деривата у једном гнезду и семантичког потенцијала основне лексеме, а посредно и то да семантички садржај основне лексеме и број деривата одражавају, више или мање доследно и системски, хијерархијски статус датог појма" (СДР1 2003: 9).

Како наводи Р. Драгићевић (2002: 111), „лексеме које сачињавају једну тематску групу заједно са својим дериватима оформљују засебне лексичке микросистеме - семантичка поља са бројним сличностима у поређењу са осталим микросистемима чији су лексички стожери чланови исте тематске групе. Уочавањем ових законитости и њиховим поређењем са системношћу у оквиру других тематских група могу се изводити важни закључци о творбеном устројству нашег језика уопште. Према томе, анализа творбеног понашања чланова једне тематске групе омогућава закључивање у вези са грађењем речи на три нивоа - на нивоу посебне лексеме, на нивоу тематске групе којој она припада и, на крају, на општем језичком нивоу."

1.2. Циљеви постављени у вези с израдом оваквог речника и данас, непуне две деценије од објављивања СДР1, и даље остају актуелни. Наиме, анализом грађе (мотивних речи и њихових деривата у оквиру одређеног гнезда) откривају се лексеме способне за семантичко и деривационо варирање, али и оне које су без таквих способности, уз утврђивање продуктивности елемената семантичког садржаја и њиховог утицаја на семантичку и деривациону дисперзију одабраних мотивних речи, као и утицај категорије речи у иницијалном положају на тип и правац деривације. Један од важних циљева јесте и попис лексема и лексичко-семантичких група које чине основу лексичког система српског језика (Гортан-Премк 2002: 104-105). Рад на прикупљању и обради грађе која је обухваћена првом свеском Семантичко-деривационог речника, почео је већ 2000. године, да би наредних година било настављено истраживање према установљеним принципима, што је резултирало другом свеском, како смо видели, објављеном три године након прве.

1.3. Наравно, таква лексикографска дела нису могла остати без одјека у србистици, у којој је још и данас уочљив њихов утицај на семантичко-дериватолошка и лексиколошка истраживања. Овом приликом, илустрације ради, наводимо само она која су израђена по принципима семантичко-деривационог гнезда. С именичким мотиваторима то су гнезда мотивисана именицама кућа (Ђуровић

\footnotetext{
${ }^{1}$ У даљем тексту СДР1 односно СДР2.
} 
2004), земьа (Иванић 2015), брат (Дражић 2017) и ильива (Ајџановић 2020). Придев добар обрађен је као модел и прилог будућем семантичко-деривационом речнику (Драгићевић 2001), а тематски шире осмишљено је истраживање о придевима са значењем људских особина као део Семантичко-деривационог речника српског језика (Драгићевић 2002). Такође је формирано и гнездо придева с другачијом семантиком - бео (Илић 2017). У фокусу једног рада је семантичко-деривациона анализа броја пет (Лазић-Коњик - Вуловић 2007). Међу истраживањима има и оних посвећених појединачним глаголима, какво је гнездо с мотивним глаголом радити (Гочанин 2005). Ипак, један од најзначајнијих резултата представља докторска дисертација М. Ђинђић (2013), у којој се у потпуности примењују постулати семантичко-деривационе анализе у испитивању турцизама у српском језику, приказаних управо по принципу гнезда.

Од значаја су и радови настали на основу података из СДР1 и СДР2, као што је то истраживање у духу когнитивне лингвистике, а посредством семантичкодеривационе анализе, при чему се откривају и одређени социокогнитивни концепти на примерима семантичко-деривационих гнезда основних лексема лексичко-семантичке групе 'особа' у српском језику (Васић 2017) или испитивања суфикса -ица (Штасни 2007) и -ина (Штасни 2016), који се јављају у дериватима мотивисаним називима делова људског тела. Ови речници пружају могућност и за истраживање језичког материјала на парадигматском лексичком плану, при чему се посматрају деривациона гнезда чланова антонимског пара (Драгићевић 2005).

Посматрано у ширем научном контексту може се слободно рећи да дериватолошки приступ примењен у СДР1 и СДР2 представља пионирски подухват у целокупној српској лингвистици. ${ }^{2}$ Актуелност теоријско-методолошког приступа примењеног у семантичко-деривационим речницима српског језика потврђује и међународно истраживање покренуто 2015. године у оквиру пројекта Моника, чији је руководилац Павол Штекауер (Pavol Štekauer) и којим је обухваћено 40 језика, а међу њима и српски (Štasni, Štrbac 2020). Циљ овог истраживања био је да се испитају системске и регуларне појаве у развоју деривационих мрежа уз примену нових теоријско-методолошких принципа, од којих је већина већ укључена у концепције наших речника. Чак су поједине мотивне речи припадале како нашем тако и овом међујезичком истраживању (именице око, кост и зуб, придеви стар и лош, глаголи пити и знати), што је скоро једна четвртина од укупног броја мотиватора у оквиру овог међународног истраживања, којим је обухваћено укупно 30 речи (по десет немотивисаних именица, придева и глагола у сваком од одабраних језика).

1.4. Поред научне продукције, осмишљен је и предмет намењен студентима на мастерским студијама под називом Од значења ка деривационом моделу,

${ }^{2}$ Иако је у време свог објављивања овај речник заиста био иновативан у србистици, словенском свету речници овог типа познати су одраније. На пример, једно од значајнијих лексикографских остварења свакако је Словообразовательный словарь русского языка А. Тихонова, објављен 1985. године (Тихонов 1985). Исте године творбеним гнездима бавио се M. Скаржињски (M. Skarżyński) у својој докторској дисертацији Próba zastosowania metody gniazdowej do opisu słowotwórstwa współczesnej polszczyzny и касније у речнику Mały słownik stowotwórczy języka polskiego dla cudzoziemców (Skarżyński 1989). 
где се у практичном делу студенти оспособљавају за примену семантичко-деривационих правила у креирању гнезда с одабраним мотиваторима. У оквиру овога предмета урађено је више семинарских радова, који као резултат имају оформљена семантичко-деривациона гнезда с мотиваторима из различитих тематских група: природни елементи и природне појаве (СДГ с мотиваторима киша, лед, магла, облак, дан, снег, сунцее, ваздух, зрак, вода, земља, извет и uзват), делови животињског тела и њихови продукти (poг, pen, сурла, ґушка, naпак, копито, месо), животиње (птица) и кретање животиња (летети), и делови биљке (корен). Одбрањено је и неколико мастерских радова, међу којима се посебно истичу Иванић 2015, Недовић 2016 и Хасанагић 2017.

Истраживања дериватолошког система те лексикографска дела изникла као њихов резултат значајан су допринос не само ускостручним, научним круговима већ и широј друштвеној заједници, посебно у образовном процесу, у настави српског језика као матерњег, али и нематерњег и страног језика, пре свега с ученицима који српским владају на средњем и напредном нивоу.

\section{2. Састав и структура новог семантичко-деривационог речника}

\section{1. Критеријуми за селекцију мотивних речи}

2.1.1. Након 20 година од почетка рада на овим речницима, који су, као што видимо, и данас актуелни и којима су инспирисана бројна истраживања мањег или већег обима, неопходно је наставити рад и сагледати већ уочене и донекле испитане проблеме на семантичком и деривационом плану на новој грађи. Стога се предлаже да се у следећој књизи семантичко-деривационог речника по истим основним принципима обраде тематски сродне речи којима се именују називи животињског дела тела. То су јединице које припадају домену анималне анатомије. Тачније, за анализу су одабране лексеме којима се именују видљиви делови животињског тела, као и називи унутрашњих органа и ткива те продуката животињског тела. Ове лексеме истовремено припадају и анатомској терминологији и општем лексикону, а као део лексичког инвентара говорника одражавају наивно виђење животињског света карактеристично за српску лингвокултурну заједницу. Стога из корпуса изостаје ускоспецијализована анимална анатомска терминологија која је пре свега део језичке компетенције стручњака за ову област. Називи делова тела, унутрашњих органа и ткива који су карактеристични и за људско и за животињско тело, нису укључени у материјал за анализу будући да су они већ обрађени у СДР1 и СДР2.3

${ }^{3}$ У СДР1 у функцији мотиватора обрађена је 41 лексема: бок, брада (у секундарној реализацији), брк (у секундарној реализацији), бут, врат (у лексикографску интерпретацију није укључен и животињски део тела), глава, груди, длака, зглоб, зуб (у лексикографску интерпретацију није укључен и животињски део тела), језик, кичма, кожа, кост, леђа, маља, нога, нокат (у секундарној реализацији), нос (у секундарној реализацији), око, плећа, појас, nрст (у секундарној реализацији), пупак, ребро (у лексикографску интерпретацију није укључен и животињски део тела), трбух, труn, уста (у секундарној реализацији), ухо/уво, чело, шија, капак, кук (у секундарној реализацији), лобања, стомак, чељуст, члан и чланак, вилица, мишић, сиса. У СДР2 приказана су семантичко-деривациона гнезда чији су мотиватори следећих 16 речи: гуша, желудаи, жила, жлезда, јаје, јетра, крв, лопатица, мозак, плуће, сало, срие, хрскавица, ирево, ћелија, цигер, те стога оне нису део будућег речника. 
2.1.2. Корпусну базу, дакле, чине лексеме којима се денотира део животињског тела који није својствен човеку или жени (нпр. рог, крзно, копито), или је орган с истом функцијом као код човека или жене, али у зоонимској терминологији именован посебном лексемом (нпр. виме, шкрге). У корпус су укључене и лексеме које у некој од секундарних реализација денотирају део животињског организма (нпр. бич > бичар, бичаш а. 'једноћелијска животиња која припада класи бичара Flagellata'; б. мн. 'систематски назив за праживотиње (протозое) из класе Flagellata ca једним, два или више кончастих израштаја помоћу којих се покрећу' [РСАНУ], индуктор за деривацију зоонимске лексеме представља секундарна реализација лексеме бич 'кончасти израштаји код животиња помоћу кога се крећу' [РСАНУ]). ${ }^{4}$ Међу мотиваторима нису заступљене лексеме које у својој семантичкој структури немају зоонимску реализацију као једну од секундарних, већ се оне јављају у функцији мотиватора за творбу назива за животињу која има део тела налик на ентитет именован мотивном речју, као на пример вила > вилаш 'животиња (мужјак) виластих рогова' [РСАНУ]. Термини латинског порекла такође нису део корпуса јер се одликују минималним деривационим потенцијалом (нпр. кутикула [лат. cuticula] а. анат. 'рожнати заштитни слој који прекрива тело бескичмењака [чланконожаца, црва и др.]'; б. бот. 'заштитна кожаста танка опна изграђена од кутина која покрива спољашње ћелијске мембране епидерме код биљака, нарочито на њиховим зељастим деловима, на семенкама и сл.' [РСАНУ]).

Са синхроног становишта, поред простих, немотивисаних речи у функцији мотиватора, одабране су и оне које су настале различитим творбеним процесима, а испуњавају основни услов - именују део животињског тела. ${ }^{5}$ Лексеме мотиватори домаћег су и страног порекла, а има их 55: батак, бич, бодља, бризла, бураг, виме, вуна, грива, губииа, дроб, жалаи, жаока, задак, запоњак, изнутрица, икра, једњак, каниа, кљова, кљун, копито, кора, кострет, крак, креста, крзно, крило, крљушт, лој, лубина, љуска, месо, млеко, нуика, оклоп, паниа, папак, перо, пипак, поклопач, пуздра, раље, реп, рило, рог, руно, сапи, слабина, сурла, ћуба, утроба, чекиња, шапа, шкембе, шкрге.

\section{2. Елементи и структурна организација речничког чланка}

2.2.1. Основни елемент речничког чланка јесте семантичко-деривационо гнездо, које чине мотивна реч и њени деривати. Деривационо гнездо формирано је на основу лексичке грађе РМС и РСАНУ. Осим деривата који припадају савременом стандардном језику, у гнездо су укључене и лексичке јединице које су у датим речницима оквалификоване као покрајинизми, архаизми, кованице, нераспрострањени облици и сл., који се системски уклапају, откривају механизме деривације, те употребу одређених афикса у народним говорима, па се на основу њихове творбене структуре могу уочити тенденције, али и семантич-

${ }^{4}$ Примарно значење лексеме бич гласи: 'направа за гоњење или подстицање теглеће стоке која се састоји из штапа и врпце од коже или плетене кудеље’ (РСАНУ).

${ }^{5}$ Ове су лексеме одабране као мотиватори јер је исти критеријум примењен и у СДР1 и СДР2. „Као носиоци деривационих гнезда успостављене су и изведене лексеме у случајевима када је дериват основна номинациона јединица за део људског тела (беоњача, дојка, сиса, мишић)" (СДР1 2003: 12). 
ко-деривациони потенцијали одређених творбених јединица. ${ }^{6}$ Речи са застарелом употребом такође су значајне јер неретко одражавају историјске процесе на плану деривације, нарочито када је реч о творбеним формантима, њиховој функцији и значењу које уносе у деривате. У гнезда су укључени и антропоними, који су последица творбе (нпр. Криљ-ански), мада није редак случај да деривирана јединица с обележјем апелатива постаје антропонимизирана форма, при чему долази до промене њене функције у лексичком систему (нпр. крил-оља 'во који има светле шаре са обе стране као крила' и Крилоња 'презиме').

Оваква селекција и приказ грађе у оквиру гнезда разликује се од поступака који су примењени у СДР1 и СДР2 јер су у њима „у основни текст речника унете све ексцерпиране лексеме које припадају савременом стандардном језику; лексеме које су у РМС квалификоване као застареле, покрајинске, кованице и сл. регистроване су у напоменама" (СДР1 2003: 12).

2.2.2. Мотивна реч иступа у улози одредничке речи. Уз њу се наводе етимолошки подаци уколико су неопходни за одређивање деривационог статуса мотиватора. Ова врста података даје се и у случајевима када се поједине лексеме као деривати у оквиру етимолошки интерпретиране породице речи семантички удаљавају од мотиватора и граде деривате на основу сопственог семантичког садржаја, као и у случају деполисемизације којом настају хомоними услед слабљења и распадања значењских веза међу семантичким реализацијама у оквиру одређене стуктуре. ${ }^{7}$ Следи информација о творбеној основи или основама, које представљају варијантне облике условљене гласовним алтернацијама што се јављају на творбеном шаву.

2.2.3. Уз мотивну реч такође се дају основни морфолошки и значењски подаци. За разлику од СДР1 и СДР2, у којима су дефиниције преузимане из РМС, уз минималне измене и сажимања, у речнику који се овом приликом предлаже опис семантичког садржаја јединица које улазе у састав речничког чланка настаје као резултат примене специфичног интерпретативног поступка лексикографских дефиниција у РСАНУ и РМС. Овај поступак, између осталог, подразумева издвајање семантичких компонената релевантних за појмовно идентификовање лексема. У том процесу посебно је важно издвојити семе које имају активну улогу у семантичко-деривационој дисперзији (тј. АК = активне компоненте). Стога се уводе нови симболи којима се означава управо ова компонента у семантичком садржају мотивне речи. Уз то, посебном ознаком издваја се и појмовни домен (ПД) којем дериват припада. Тако су и семантичке интерпретације деривираних јединица модификоване у односу на оне дате у дескриптивним речницима РМС и САНУ, а из њих је видљиво њихово творбено значење.

2.2.4. Деривати су такође морфолошки описани и сегментирани издвајањем творбене основе и афиксалних форманата, који су сада истакнути масним слови-

${ }^{6}$ Будући да се семантичко-деривациони речник не бави статусом и местом лексичких јединица у лексичком систему као целини, из њега су изостављене ознаке које у том погледу квалификују деривате, нпр. ков.(аница), покр.(ајински), заст.(арело) итд.

${ }^{7}$ На пример, лексеме жалаи и жаока са синхроног становишта имају статус немотивисаних речи иако су оне, етимолошки посматрано, изведенице деминутивним суфиксима -bu>-(a) ц од *жал- односно -це у жаоце или на -ька -жаока. У функцији мотиватора је балтословенско, свесловенско и прасловенско *žedlo или (стцслов.) zelo $\mathrm{n}<*$ geldlo, aculeus (Skok 1973: 670). 
ма, чиме се уједно сугерише и творбени образац по коме је одређени дериват настао. Стога се уз деривате не наводе записи у виду симбола који носе информацију о начину постанка одређене јединице будући да је он видљив на основу истакнутих форманата. Дакле, у новој верзији речника неће бити заступљени симболи ПР за префиксиране деривате, ПРс за префиксално-суфиксалне творенице и С за сложенице, који су у СДР1 и СДР2 стајали и испред свих речи добијених од неког префиксала, без обзира на то да ли су и саме настале префиксацијом, што ће допринети прецизнијем опису творбене структуре анализираних речи, али и растерећењу речничког чланка. Остају, међутим, индекси који се налазе испред сваке одреднице и који означавају њену семантичку и деривациону позицију у датом гнезду: основна лексема, носилац деривационог гнезда - има индекс 0, првостепени деривати уведени су редним бројем I, другостепени редним бројем II итд. Давање предности римским цифрама у односу на арапске мотивисано је бољим визуелним раздвајањем деривационог степена од редног броја деривата одређеног степена који је (и даље)

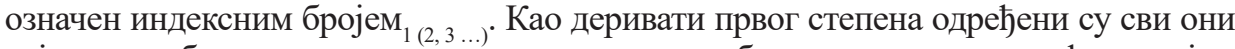
којима творбена основа потиче од мотивне речи било да су настали суфиксацијом било префиксацијом, префиксално-суфиксалном творбом или слагањем. Ипак, деривати ће бити навођени с обзиром на примењени творбени поступак, при чему ће, као и у СДР1 и СДР2, прво бити наведени суфиксали, потом префиксали и префиксално-суфиксална образовања те, на крају, композите. Дефинисање деривата пак заснива се на творбеној семантици, на њиховом творбеном значењу.

Ове промене илустроваћемо елементима из семантичко-деривационог гнезда лексеме $y c m a$, упоредо датим по некадашњем и иновираном моделу.

\section{СДР1 (2003: 334)}

$3_{6}<2$ усн-ица дем. и хип. од усна

ПР $1<3_{6}$ на-усница ж терм. анат. 1. длачице над горњом усном, почетак бркова. 2. део лица између горње усне и носа.

ПРс $1_{1}<0$ без-уст-б, -а, -о квалит. прид. који је без уста.

$\Pi$ Рс $2_{1}<\Pi$ Рс1 $1_{1}$ безуст-ост ж терм. мед. стање онога који је без уста, astomia.

$\Pi Р \mathrm{Pc} 1_{2}<0$ за-уст-ити, -им пф., тр. отворити уста (да се што каже), покушати рећи, хтети или почети говорити (а не изрећи). [+Obj (A)]

$\mathrm{Cl}_{21}<0$ широк-о-уст-ø, - $\mathrm{a}$, -о квалит. прид. који има широка уста.

$\mathrm{C} 2_{1}<\mathrm{C} 1_{21}$ широкоуст-ица ж терм. мед. ненормално велика ширина уста.

\section{Модификовани модел}

III $_{1}$ усн-ица дем. и хип. од усна

$\mathrm{IV}_{1}$ на-усница ж 1. длачице над горњом усном; 2. део лица између горње усне и носа

$\mathrm{I}_{2}$ без-уст-ø, -а, -о који је без уста

$\mathrm{II}_{2}$ безуст-ост ж стање онога који је без уста, astomia

$\mathrm{I}_{3}$ за-уст-ити, -им сврш., отворити уста (да се што каже), покушати рећи, хтети или почети говорити (а не изрећи)

$\mathrm{I}_{4}$ широк-о-уст-б, -а, -о који има широка уста

$\mathrm{II}_{3}$ широкоуст-ица ж ненормално велика ширина уста

2.2.5. Иако су и горе наведене промене осетне, ипак се једно од кључних питања односи на устројство гнезда. Чињеница је да су поједина гнезда веома 
разуђена и с великим бројем деривата, као што има и оних мањег обима, а самим тим и једноставније структуре. Чињеница је такође и то да семантичко-деривационо гнездо има слојевиту структуру хијерархијски устројену: највиша организациона јединица јесте гнездо, унутар којег се визуелно издвајају микрогнезда.

Деривати првог степена распоређују се азбучним редом јер се непосредно везују за основну реч. Сви остали деривати вишег степена приказују се сукцесивно, у деривационом низу, надовезујући се непосредно на јединицу од које се изводе. У сложеним ситуацијама када се деривациони скуп састоји од мотивне речи и деривата различитог степена, сваки следећи се сматра дериватом вишег степена без обзира на начин творбе, што се истиче и увученим редом. Овај поступак илустрован је следећим подацима на основу СДР1:

\section{СДР1 (2003: 76-77)}

0 брк

$1_{7}<0$ брк-ат, -а, -о квалит. прид. 1. који има (велике) бркове; коме су израсли бркови. 2. који има вршике или израштаје (о биљци).

$2<1$, бркат-ити, -имимпф., медиј. добијати бркове.

ПР $1_{1}<2$ о-бркатити, -им пф., медиј. добити бркове, постати бркат.

\section{0 брк}

$\mathrm{I}_{7}$ брк-ат, -a, -о 1. који има (велике) бркове; коме су израсли бркови. 2. који има вршике или израштаје (о биљци) бркове.

II бркат-ити, -им несврш. добијати

III $_{1}$ о-бркатити, -им сврш. добити бркове, постати бркат

2.2.6. Након речничког чланка даје се табеларни приказ с подацима који у највећој мери одређују творбене и семантичке карактеристике деривационог гнезда посматране речи.

Када се сви описани елементи укључе, речнички чланак семантичко-деривационог речника, израђен по иновираном моделу, имаће структуру приказану у табели која следи.

\section{СДГ X}

Етимолошке напомене (уколико су неопходне)

Творбена основа (ТО)

Значењска структура мотивне речи

Активне компоненте означене симболима (АК)

Појмовни домени означени симболима (ПД)

Семантичко-деривационо гнездо

$\mathrm{I}_{1}$ ДЕРИВАТ морфолошке ознаке (АК) > дефиниција (ПД)

$\mathrm{II}_{2}$ ДЕРИВАТ морфолошке ознаке (АК) > дефиниција (ПД)

$\mathrm{III}_{3}$ ДЕРИВАТ морфолошке ознаке (АК) > дефиниција (ПД)

Прегледне табеле:

a) с творбеним карактеристикама деривата;

б) са семантичким карактеристикама деривата

На основу овако предочених података јасно се може стећи увид у дериваци- 
они потенцијал речи, „под којим се подразумевају две компоненте - деривациони обим и деривациони домет. Деривациони обим обухвата укупан број деривата различитог степена деривације, директно или индиректно мотивисаних одређеном речју, док се термином деривациони домет указује на њихову семантичку разноврсност, тј. на разноврсност домена којима припадају реалије именоване дериватима” (Штрбац 2018: 87).

3. Пример речничког чланка: семантичко-деривационо гнездо лексеме руно

3.1. У овом делу рада на примеру лексеме руно представићемо модел речничког чланка базиран на новоустановљеним принципима обраде. Избор лексеме руно наметнуо се као посве оправдан не само због тога што је она део планираног корпуса него пре свега због чињенице да је довољно илустративна за представљање иновираних принципа обраде.

3.2. П. Скок (1973: 171) наводи следеће варијантне облике: рун м (17. в. Дубровчани) = руна ж (хрв. и кајк.) = руно с (13. в. Вук) и реч одређује као свесловенску и прасловенску, без паралела у балтичкој групи. Уз њу везује следећа значења 1. 'velius, вуна'; 2. 'плод' (њива под руном, метафора); 3. 'име овци'.

У савременом језику промењена је семантичка структура ове лексеме. Примарна реализација и дијахроно и синхроно садржи исти семантички садржај, док је секундарно метафорично значење 'плод' - вероватно индуковано асоцијацијама по сличности, структури, обиму, изгледу - неактивно са синхроног становишта. Исто важи и за значење 'име овце', које је настало под утицајем синегдохе засноване на односу део : целина, по моделу 'она која има $\mathrm{X}$, чији је X део тела', при чему је X семантички садржај примарне реализације мотивног појма (руно). Значење које није обухваћено етимолошком лексикографском интерпретацијом, обележено као фигуративно - 'једногодишњи род, летина', с полазним доменом успоставља везу метафоричног типа, при чему је активна темпорална компонента (од једног до другог стрижења).

3.3. Декомпоновањем примарне реализације мотивне речи руно издвајају се компоненте садржане у њеној појмовној вредности - компонента блиска архисеми која носи информацију семантичког типа - део животињског тела 'природни покривач', затим и диференцијална сема високог ранга 'длаке' с квантификаторима и квалификаторима 'густе и дугачке' којима се сугерише изглед именованог ентитета, те компонента која се односи на посесора 'на животињама, најчешће овцама'. Део лексикографске интерпретације примарног значења лексеме руно 'вуна која израсте на овци од једног до другог стрижења' не садржи компоненте којима ће се индуковати деривати, те неће бити укључена у дефинисање овога мотиватора у семантичко-деривационом речнику, као што се ни семантички садржај фигуративне секундарне реализације 'једногодишњи род, летина' не активира у даљим семантичко-деривационим процесима, те се сматра нерелевантним за посматрано гнездо. 
СДГ руно

ТО: 8 рун-, рунд-, руњ-

руно с 'природни покривач од густе, дугачке длаке на животињама (најчешће овцама)'

Активне компоненте у семантичком садржају лексеме руно и њихове ознаке:

ЦСС = целокупан семантички садржај мотивне речи; $\mathrm{M}=$ мањих димензија од уобичајеног; В = већих димензија од уобичајеног; $\Phi=$ функција; И = изглед (густина, дужина, боја, мекоћа и др.)

Појмовни домени деривата и њихове ознаке:

$\mathrm{O}=$ особина; Ж = животиња; $\Pi=$ предмет $\left(\Pi_{д}=\right.$ део предмета); ДЖТ = део животињског тела; $\mathrm{C}=$ стање $\left(\mathrm{C}_{\text {и }}=\right.$ инхоативно, $\mathrm{C}_{\text {ин }}=$ ингресивно); Б (биљка); ДЧТ = део човековог тела; Ч = човек

$\mathrm{I}_{1}$ рун-ав, -a, -о (ЦСС) > 1. који је длакав, руњав, маљав $(\mathbf{O}) ;(И)>2$. фиг. који је груб, неосетљив, окорео $(\mathbf{O})$

$\mathrm{II}_{1}$ рунава ж (И) > крава с рундавом длаком (Ж)

$\mathrm{I}_{2}$ рун-аст, -a, -о (ЦСС) > 1. који има густо руно, који је обрастао руном $(\mathbf{O}) ;(И)$ $>2$. који је као руно $(\mathbf{O})$

І који је као руно (О)

$\mathrm{I}_{4}$ рун-ац, -нца м $(\Phi)>$ вунени покривач $($ П $)$

$\mathrm{I}_{5}$ рун-ашце с (ЦСС + М) > дем. од руно (ДЖТ)

$\mathrm{I}_{6}$ рун-ен, -а, -о $(\Phi)>$ који је од руна $(\mathbf{O})$

$\mathrm{I}_{7}$ рун-ити (се), руним несврш. (ЦСС) >добијати руно $\left(\mathbf{C}_{\mathbf{n}}\right)$

$\mathrm{II}_{2}$ за-рунити (се), заруним (се) сврш. (ЦСС) > почети рунити, почети добивати руно $\left(\mathbf{C}_{\text {ин }}\right)$

III 1 зарун-авети (се), ијек. заруњавјети (се), -уњавим (се) несврш. (ЦСС) > постајати рунав, длакав $\left(\mathbf{C}_{\mathbf{u}}\right)$

$\mathrm{I}_{8}$ рун-ка ж (И) > биљка Artemisia scoparia, која изгледом својих листова подсећа на руно (Б)

$\mathrm{I}_{9}$ рун-ски, -a, -о (ЦСС) > који се односи на руно $(\mathbf{O})$

$\mathrm{I}_{10}$ рун-це с (ЦСС + М) > дем. од руно (ДЖТ)

$\mathrm{I}_{11}$ рун-чица ж (ЦСС) > овца (Ж)

$\mathrm{I}_{12}$ рунд-ав, -а, -о (И) > који има бујну коврчаву длаку као руно (О)

${ }^{8}$ Могла би се успоставити још и основа руm- од рута = pуњ $a(\mathrm{PMC})$, за шта је, међутим, тешко дати етимолошко образложење, при чему је још теже оправдати је са становишта савременог српског језика, а посебно стога што и П. Скок у свом речнику лексему рута обрађује у оквиру засебног лексикографског чланка (Skok 1973: 176). 
II ${ }_{3}$ рунд-а ж (И) > рундава животиња (Ж)

$\mathrm{II}_{4}$ рунд-ов, -ова м (И)> пас рундаве длаке (Ж)

$\mathrm{III}_{2}$ рундов-чина м $(И+\mathrm{B})>$ аугм. од рундов (ДЖТ)

$\mathrm{II}_{5}$ рунд-аст,-а, -о (И) > који има бујну коврчаву длаку као руно (О)

$\mathrm{I}_{13}$ руњ-а ж (мн.) $(И)>1$. длака на животињама и на неким деловима човечјег тела (ДЖТ/ДЧТ); (И)>2. длака на тканини $\left(\boldsymbol{\Pi}_{д}\right)$

$\mathrm{II}_{6}$ руњ-ав, -а, -о (ЦСС) $>1$. који је обрастао руњом, длаком $(\mathbf{O}) ;(И)>2$. који изгледа као обрастао длаком, прекривен длакастим нитима (о тканини) (О); (И) > 3 . сличан руњама, вунаст $(\mathbf{O})$

III ${ }_{3}$ руњав-ост, -ости ж (ЦСС) > особина онога који је руњав (О)

III $_{4}$ руњав-ац, -авца м (И)> онај који је руњав $(\mathbf{\Psi})$

$\mathrm{IV}_{1}$ руњ-а м (И)> хип. од руњавац $(\mathbf{4})$

$\mathrm{IV}_{2}$ руњ-о м (И) > хип. од руњавац $(\mathbf{4})$

$\mathrm{III}_{5}$ руњав-ица ж (И) > биљка Hieracium pilosella, која изгледом цвета и стабла подсећа на руно (Б)

$\mathrm{IV}_{3}$ руњавич-ина ж $(И)>$ биљка Hieracium pilosella, која изгледом цвета и стабла подсећа на руно (Б)

$\mathrm{III}_{6}$ руњав-ети, руњавим несврш. (ЦСС) > постајати руњав, добијати руно $\left(\mathbf{C}_{\mathbf{u}}\right)$

$\mathrm{IV}_{4}$ за-руњавети (се), -уњавим (се), ијек. заруњавјети (се) (ЦСС) > постати руњав, длакав $\left(\mathbf{C}_{\mathbf{n}}\right)$

$\mathrm{III}_{7}$ руњав-ити, руњавим несврш. (ЦСС) > постајати руњав, добијати руно $\left(\mathbf{C}_{\mathbf{n}}\right)$

$\mathrm{IV}_{5}$ за-руњавити (се),-уњавим (се) сврш. (ЦСС) > постати руњав, длакав $\left(\mathbf{C}_{\mathbf{u}}\right)$

$\mathrm{IV}_{6}$ об-руњавити, -им сврш. (ЦСС) > постати руњав, одлакавити, добити густу длаку $\left(\mathbf{C}_{\mathbf{n}}\right)$

$\mathrm{IV}_{7}$ о-руњавити, -им сврш. (ЦСС) > постати руњав, зарасти у длаку, закосматити $\left(\mathbf{C}_{\mathbf{u}}\right)$

$\mathrm{II}_{7}$ руњ-ак, -њка м (И)> коврчаст прамен длаке (ДЧТ)

$\mathrm{II}_{8}$ руњ-аст, -а, -о (ЦСС) > 1. који је длакав, руњав, маљав $(\mathbf{O}) ;(И)>2$. фиг. који је груб, неосетљив, окорео $(\mathbf{O})$

$\mathrm{II}_{9}$ руњ-ат, -а, -о (ЦСС) > 1. који је длакав, руњав, маљав $(\mathbf{O}) ;(И)>2$. фиг. који је груб, неосетљив, окорео (О)

$\mathrm{II}_{10}$ руњ-ика ж $(И)>$ биљка Hieracium pilosella, која изгледом цвета и стабла подсећа на руно (Б)

$\mathrm{I}_{14}$ бел-о-рун-б, -а, -о (ЦСС + И) > који има бело руно, белу вуну $(\mathbf{O})$

$\mathrm{I}_{15}$ густ-о-рун-ө, -а, -о (ЦСС + И) > који има густо руно $(\mathbf{O})$

$\mathrm{I}_{16}$ дуг-о-рун-ø, -a, -о (ЦСС + И) > који има дуго руно $(\mathbf{O})$

$\mathrm{I}_{17}$ злат-о-рун-б, -а, -о (ЦСС + И) > који има златно руно $(\mathbf{O})$

$\mathrm{I}_{18}$ мек-о-рун-б, -a, -о (ЦСС + И) > који има меко руно $(\mathbf{O})$

$\mathrm{I}_{19}$ плав-о-рун-б, -a, -о (ЦСС + И) > који има плаво руно $(\mathbf{O})$

$\mathrm{I}_{20}$ рун-о-лист-б м (И) > биљка Leontopodium, чије је стабло и лишће обрасло густим длачицама (Б) 
$\mathrm{I}_{21}$ свилен-о-рун-ø,-а, -о (ЦСС + И) > који има руно као свила $(\mathbf{O})$

$\mathrm{I}_{22}$ свил-о-рун-о, -a, -о (ЦСС + И) > који има руно као свила $(\mathbf{O})$

$\mathrm{I}_{23}$ танк-о-рун-ø, -a, -о (ЦСС + И) $>$ који је танког, финог руна, свилорун $(\mathbf{O})$

Табела 1: Деривациона структура гнезда

\begin{tabular}{|c|c|c|c|c|}
\hline $\begin{array}{l}\text { степен } \\
\text { деривације }\end{array}$ & \multirow[t]{2}{*}{ први } & \multirow[t]{2}{*}{ други } & \multirow[t]{2}{*}{ трећи } & \multirow[t]{2}{*}{ четврти } \\
\hline врста речи & & & & \\
\hline именице & $\begin{array}{l}6 \text { суф. }+1 \text { слож. } \\
=7\end{array}$ & $\begin{array}{l}4 \text { суф. }+1 \\
\text { конв. }=5\end{array}$ & 3 суф. $=4$ & 3 суф. $=4$ \\
\hline придеви & $\begin{array}{l}6 \text { суф. }+9 \text { слож. } \\
=\mathbf{1 5}\end{array}$ & 4 суф. $=4$ & 0 & 0 \\
\hline глаголи & 1 суф. $=1$ & 1 преф. = 1 & 3 преф. $=3$ & 3 преф. \\
\hline укупно & 23 & 10 & 7 & 7 \\
\hline \multicolumn{4}{|c|}{ укупно деривата } & 47 \\
\hline
\end{tabular}

Табела 2: Семантичка структура гнезда

\begin{tabular}{|c|c|c|c|c|c|c|c|c|c|c|c|}
\hline ПД & 0 & $\Psi$ & П & $\Pi$ & пЖТ & $C$ & $C$ & 5 & ДЧт & $\mathrm{U}$ & продуктивност АК \\
\hline AK & & & & $1_{\text {д }}$ & дл1 & $C_{\text {и }}$ & $C_{\text {ин }}$ & & & & \\
\hline ЦСС > & 8 & 1 & & & & 8 & 1 & & & & 18 \\
\hline ЦCC+ M > & & & & & 2 & & & & & & 2 \\
\hline ЦСС + И> & 9 & & & & & & & & & & 9 \\
\hline$\Phi>$ & 1 & & 1 & & & & & & & & 2 \\
\hline И> & 9 & 3 & & 1 & 1 & & & 6 & 2 & 3 & 25 \\
\hline И+ В > & & & & & 1 & & & & & & 1 \\
\hline $\begin{array}{l}\text { продуктивност } \\
\text { ПД }\end{array}$ & 27 & 4 & 1 & 1 & 4 & 8 & 1 & 6 & 2 & 3 & \\
\hline
\end{tabular}

\section{4. Уместо закључка}

4.1. Речници организовани по принцупу гнезда представљају специјалне лингвистичке речнике. Они се свакако примарно ослањају на информације садржане у граматикама и дескриптивним речницима одређеног језика, али се у њима дају нове информације семантичко-деривационог типа у вези с мотивном речју и дериватима који улазе у састав њеног гнезда. Веза између мотиватора и деривата исказује се утврђивањем деривационог статуса, односно степена и типа деривације. Укључивањем тематског, семантичког и деривационог критеријума омогућава се системско сагледавање односа између типа и броја деривата у једном гнезду и семантичког потенцијала основне лексеме, чиме се одражава хијерархијски статус одређеног појма у оквиру тематске скупине којој припада. Од посебног је значаја идентификација и утврђивање про- 
дуктивности начина настајања деривата, као и стварање могућности да се провери да ли тип и правац семантичких и деривационих модификација зависе од категорије речи у функцији мотиватора.

4.2. Иновативни елементи у структури речничког чланка, пре свега унутар деривационог гнезда, на првом месту навођење активних компонената значења које се преносе у семантички садржај деривата и на основу којих се изводи њихово творбено значење, а које их одређује као припаднике одређеног појмовног домена, доприносе успостављању баланса између деривационог и семантичког аспекта гнезда на начин на који он није био присутан у СДР1 и СДР2. То сматрамо веома важним будући да се таквом интерпретацијом постиже бољи увид у укупан потенцијал како мотиватора тако и деривата, али и на нивоу посматране лексичке групе, којом су обухваћени називи делова животињског тела.

4.3. На основу податка из оваквог речника може се стећи увид у продуктивне и непродуктивне творбене процесе, моделе, творбене форманте и њихову улогу у оквиру творбе јединица које припадају одређеним лексичко-семантичким скуповима, те се на основу тога може извести и закључак о статусу деривата у оквиру лексикона српског језика. Б. Тафра истиче значај творбеног критеријума као једног од доказа за постојање хомонимијског односа међу лексемама као и поузданог средства за разграничавање полисемије од хомонимије (Tafra 2003: 197).

4.4. На основу састава гнезда могуће је израчунати полисемијски индекс (колико лексема има колико значења), те колико деривата учествује у даљој творби, колико има деривата првог, другог или неког вишег степена, колико деривата се одликује моносемијом, а могуће је пратити и однос полисемије и деривације, тј. да ли је вишезначност повезана са степеном деривације одређене јединице и др.

4.5. М. Радовић Тешић (2004: 171) сматра да су овакви речници одлична подлога за системска (и синтетичка) истраживања творбених морфема у српском језику, те да ће много конкретних примера пружити могућност да се поузданије разреше неке дилеме како при систематизацији морфема у језику тако и у уочавању законитости њиховог функционисања при спајању односно слагању с различитим основама. Даљим радом на семантичко-деривационим речницима можемо бити ближи одговору на једно од фундаменталних питања - „да ли тип семантичких и деривационих модификација зависи од категорије основне, полазне речи и да ли су именице, као што се претпоставља, продуктивније у семантичком и деривационом варирању од других категорија речи" (Коњик 2006: 100).

4.6. Чак и огледна истраживања појединачних лексема или лексема које припадају одређеној тематској групи, од нарочитог су значаја уколико одговарају на питања која се тичу узрока творбе одређене семантичке класе деривата у зависности од семантичког садржаја мотивне речи и законитости које регулишу деривационе процесе. „Подаци о деривационом потенцијалу лексема могу бити одлични показатељи њиховог места у лексикону, али и места појмова који су њима обележени у концептуалном систему говорника неког језика, на основу чега се могу извести дубљи закључци у вези са сликом света утемељеној у једној говорној заједници" (Штрбац 2018: 86). 
4.7. На крају, као још један, можда и најважнији квалитет оваквог приступа семантичко-деривационом речнику треба да истакнемо чињеницу да - после непуне две деценије паузе у продукцији већих лексикографских дела посвећених оваквом начину изучавања српског лексикона - он представља први организовани напор који ће резултовати једним синтетичним делом, чиме ће, надамо се у догледној будућности, бити настављена традиција установљена СДР1 и СДР2.

\section{Цитирана литература}

Ајџановић, Милан. «Називи за шљиву у Речнику српскохрватскога књижевног језика». Славянская дэрыватаграфія. Минск: Нацыянальная акадэмія навук Беларусі - Беларускі камітэт славістаў - Камісія па славянскім словаўтварэнні, 2020, 103-117.

[Ajdžanović, Milan. «Nazivi za šljivu u Rečniku srpskohrvatskoga književnog jezika». Slavjanskaja deryvatagrafija. Minsk: Nacyjanal'naja akademija navuk Belarusi - Belaruski kamitet slavistaŭ - Kamisija pa slavjanskim slovaŭtvarenni, 2020, 103-117]

Васић, Вера. «Семантичко-деривационом анализом до социокогнитивног концепта (на примерима основних лексема лекисичко-семантичке групе 'особа' у српском језику)». [У:] Рајна Драгићевић (ур.) Путевима речи. Зборник радова у част Даринки Гортан Премк. Београд: Филолошки факултет, 2017, 345-374.

[Vasić, Vera. «Semantičko-derivacionom analizom do sociokognitivnog koncepta (na primerima osnovnih leksema lekisičko-semantičke grupe 'osoba' u srpskom jeziku)». [U:] Rajna Dragićević (ur.) Putevima reči. Zbornik radova u čast Darinki Gortan Premk. Beograd: Filološki fakultet, 2017, 345-374]

Гортан-Премк, Даринка. «Семантичко-деривациони речник српског језика». Дескриптивна лексикографија стандардног језика и њене теоријске основе. Нови Сад - Београд: Матица српска - Српска академија наука и уметности, 2002, 103-110.

[Gortan-Premk, Darinka. «Semantičko-derivacioni rečnik srpskog jezika». Deskriptivna leksikografija standardnog jezika i njene teorijske osnove. Novi Sad Beograd: Matica srpska - Srpska akademija nauka i umetnosti, 2002, 103-110]

Гочанин, Мирјана. «Семантичко-деривационо гнездо лексеме радити». Наш језик XXXVI, 2005: 104-125.

[Gočanin, Mirjana. «Semantičko-derivaciono gnezdo lekseme raditi». Naš jezik XXXVI, 2005: 104-125]

Драгићевић, Рајна. «Прилог Семантичко-деривационом речнику српскога језика (Деривационо гнездо придева добар)». Наш језик XXXIV/1-2, 2001: 145-151.

[Dragićević, Rajna. «Prilog Semantičko-derivacionom rečniku srpskoga jezika (Derivaciono gnezdo prideva dobar)». Naš jezik XXXIV/1-2, 2001: 145-151]

Драгићевић, Рајна. «Придеви са значењем људских особина као део Деривационосемантичког речника српског језика». Дескриптивна лексикографија стандардног језика и њене теоријске основе. Нови Сад - Београд: Матица српска - Српска академија наука и уметности, 2002, 111-117.

[Dragićević, Rajna. «Pridevi sa značenjem ljudskih osobina kao deo Derivacionosemantičkog rečnika srpskog jezika». Deskriptivna leksikografija standardnog jezika i njene teorijske osnove. Novi Sad - Beograd: Matica srpska - Srpska akademija nauka i umetnosti, 2002, 111-117]

Драгићевић, Рајна. «Деривациона гнезда чланова антонимског пара». Србистички прилози: зборник у част професора Славка Вукомановића. Београд: Филолошки 
факултет, 2005, 93-98.

[Dragićević, Rajna. «Derivaciona gnezda članova antonimskog para». Srbistički prilozi: zbornik u čast profesora Slavka Vukomanovića. Beograd: Filološki fakultet, 2005, 93-98]

Дражић, Јасмина. «Семантичко-деривационо гнездо лексеме брат и његове културолошке импликације у Српском рјечнику Вука Ст. Караџића. [У:] Рајна Драгићевић (ур.) Путевима речи. Зборник радова у част Даринки Гортан Премк. Београд: Филолошки факултет, 2017, 415-426.

[Dražić, Jasmina. «Semantičko-derivaciono gnezdo lekseme brat i njegove kulturološke implikacije u Srpskom rječniku Vuka St. Karadžića. [U:] Rajna Dragićević (ur.) Putevima reči. Zbornik radova u čast Darinki Gortan Premk. Beograd: Filološki fakultet, 2017, 415-426]

Ђинђић, Марија. Турцизми у савременом српском књижевном језику (семантичко-деривациона анализа). Докторска дисертација. Београд: Филолошки факултет, 2013. <https://nardus.mpn.gov.rs/handle/123456789/4074>01.06.2021.

[Đinđić, Marija. Turcizmi u savremenom srpskom književnom jeziku (semantičkoderivaciona analiza). Doktorska disertacija. Beograd: Filološki fakultet, 2013]

Ђуровић, Сања. «Деривационо гнездо лексеме кућа - творбено-семантичка анализа». Наслеђе 1/1, 2004: 83-103.

[Đurović, Sanja. «Derivaciono gnezdo lekseme kuća - tvorbeno-semantička analiza». Nasleđe 1/1, 2004: 83-103]

Иванић, Мирела. «Семантичко-деривационо гнездо лексеме земља». Прилози проучавању језика 46, 2015: 57-72.

[Ivanić, Mirela. «Semantičko-derivaciono gnezdo lekseme zemlja». Prilozi proučavanju jezika 46, 2015: 57-72]

Илић, Мирјана. «Деривационо гнездо придева бео у српском језику». [У:] Рајна Драгићевић (ур.) Путевима речи. Зборник радова у част Даринки Гортан Премк. Београд: Филолошки факултет, 2017, 441-459.

[Ilić, Mirjana. «Derivaciono gnezdo prideva beo u srpskom jeziku». [U:] Rajna Dragićević (ur.) Putevima reči. Zbornik radova u čast Darinki Gortan Premk. Beograd: Filološki fakultet, 2017, 441-459]

Коњик, Ивана. «Семантичко-деривациони речник. Свеска 2». Наш језик XXXVII/1-4, 2006: 97-102.

[Konjik, Ivana. «Semantičko-derivacioni rečnik. Sveska 2». Naš jezik XXXVII/1-4, 2006: 97-102]

Лазић-Коњик, Ивана, Наташа Вуловић. «Семантичко-деривациона анализа броја nет». Наш језик XXXVIII/1-4, 2007: 43-64.

[Lazić-Konjik, Ivana, Nataša Vulović. «Semantičko-derivaciona analiza broja pet». Naš jezik XXXVIII/1-4, 2007: 43-64]

Недовић, Вељко. Семантичко-деривациона гнезда лексема: poг, pen, сурла, ғушка, папак и копито. Мастерски рад. Нови Сад: Филозофски факултет, 2016.

[Nedović, Veljko. Semantičko-derivaciona gnezda leksema: rog, rep, surla, njuška, papak i kopito. Masterski rad. Novi Sad: Filozofski fakultet, 2016]

Радовић-Тешић, Милица. «Семантичко-деривациони речник, Свеска 1: Човек делови тела, ед. Лингвистичке свеске 3, изд. Филозофски факултет, Одсек за српски језик и лингвистику, Нови Сад 2003, 373 стр.». Наш језик XXXV/1-4, 2004: 169-173.

[Radović-Tešić, Milica. «Semantičko-derivacioni rečnik, Sveska 1: Čovek — delovi tela, ed. Lingvističke sveske 3, izd. Filozofski fakultet, Odsek za srpski jezik i lingvistiku, 
Novi Sad 2003, 373 str.». Naš jezik XXXV/1-4, 2004: 169-173]

СДР1: Семантичко-деривациони речник. Свеска 1: Човек - делови тела (ред. Гортан-Премк Даринка, Вера Васић, Љиљана Недељков). Филозофски факултет: Нови Сад, 2003.

[SDR1: Semantičko-derivacioni rečnik. Sveska 1: Čovek - delovi tela (red. GortanPremk Darinka, Vera Vasić, Ljiljana Nedeljkov). Filozofski fakultet: Novi Sad, 2003]

СДР2: Семантичко-деривациони речник. Свеска 2: Човек - унутрашњи органи и ткива, психофизиолошка стања и радње, психофизичке особине, сродство (ред. Гортан-Премк Даринка, Вера Васић, Рајна Драгићевић). Филозофски факултет: Нови Сад, 2006.

[SDR2: Semantičko-derivacioni rečnik. Sveska 2: Čovek - unutrašnji organi i tkiva, psihofiziološka stanja i radnje, psihofizičke osobine, srodstvo (red. Gortan-Premk Darinka, Vera Vasić, Rajna Dragićević). Filozofski fakultet: Novi Sad, 2006]

Тихонов, Александр Николаевич. Словообразовательный словарь русского языка в 2 томах. Том 1 А-П, Том 2 П-Я. Москва: Русский язык, 1985.

[Tikhonov, Aleksandr Nikolaevich. Slovoobrazovatel'nyı̌ slovar' russkogo iāzyka v 2 tomakh. Tom 1 A-P, Tom 2 P-Iâ. Moskva: Russkiı̌ iāzyk, 1985]

Хасанагић, Снежана. Семантичко-деривационо гнездо лексема иявет и ц̧ват. Мастерски рад. Нови Сад: Филозофски факултет, 2017.

[Hasanagić, Snežana. Semantičko-derivaciono gnezdo leksema cvet i cvat. Masterski rad. Novi Sad: Filozofski fakultet, 2017]

Штасни, Гордана. «Деривати на -ица од назива делова људског тела». Прилози проучавању језика 38, 2007: 93-106.

[Štasni, Gordana. «Derivati na -ica od naziva delova ljudskog tela». Prilozi proučavanju jezika 38, 2007: 93-106]

Штасни, Гордана. «Деривати са суфиксом -ина мотивисани соматизмима». Књижевност и језик LXIII/3-4, 2016: 243-252.

[Štasni, Gordana. «Derivati sa sufiksom -ina motivisani somatizmima». Književnost i jezik LXIII/3-4, 2016: 243-252]

Štasni, Gordana, Gordana Štrbac. Derivational networks in Serbian. (In:) Lívia Körtvélyessy, Alexandra Bagasheva and Pavol Štekauer (eds) Derivational Networks Across Languages. Series: Trends in Linguistics. Studies and Monographs. Berlin: De Gruyter Mouton, 2020, 85-92.

Штрбац, Гордана. «Деривациони потенцијал придева у српском језику - ономасиолошки и когнитивни приступ». Зборник Матице српске за филологију и лингвистику LXI/1, 2018: 85-99.

[Štrbac, Gordana. «Derivacioni potencijal prideva u srpskom jeziku - onomasiološki i kognitivni pristup». Zbornik Matice srpske za filologiju i lingvistiku LXI/1, 2018: 85-99]

Skarżyński, Mirosław. Mały słownik słowotwórczy języka polskiego dla cudzoziemców. Kraków: Wydawnictwo Uniwersytetu Jagiellońskiego, 1989.

Skok, Petar. Etimologijski rječnik hrvatskoga ili srpskoga jezika. Zagreb: Jugoslavenska akademija znanosti i umjetnosti, 1973.

Tafra, Branka. «Jednost semantike i tvorbe - Semantičko-derivacioni rečnik, sveska 1: Čovek - delovi tela (redaktorice Darinka Gortan-Premk, Vera Vasić i Ljiljana Nedeljkov). Filozofski fakultet. Novi Sad 2003». Filologija, 2003: 192-199. <https://hrcak.srce. $\mathrm{hr} / 164714>01.06 .2021$ 
Gordana Štasni

Gordana Štrbac

Milan Ajdžanović

\title{
AN INNOVATED CONCEPT OF THE SEMANTIC-DERIVATIONAL DICTIONARY OF THE SERBIAN LANGUAGE ON THE EXAMPLE OF THE RUNO LEXEME NEST
}

\begin{abstract}
Summary
This paper discusses with new principles of compiling the semantic-derivational dictionary. The idea is to present the derivational nests of words denoting the animal body parts in Serbian. This paper proposes a nest structure in the future innovated dictionary using the motivating word runo (fleece) and its nest as an illustrative material. The nest includes 47 derivatives in total. Unlike the approach used in its notable predecessors (Semantic-Derivational Dictionary, Volume 1 (2003) and Volume $2(2006))$ - the one given in this dictionary equally focuses on semantics and derivation. Namely, each word given in the nest is provided with the so-called active components of meaning which help us establish its derivational meaning as well as shed light on relations within the words in the nest and the semantic potential of the motivating word.

Keywords: Serbian language, semantic-derivational dictionary, derivational nest, lexeme runo (fleece).
\end{abstract}

